\title{
Effects of harbour and ship channel construction on breeding seabirds
}

\author{
Effekter av hamn- och kanalkonstruktion på häckande sjöfåglar
}

\author{
RAUNO A. YRJÖLÄ, JUKKA A. RINTALA, HANNU PIETIÄINEN \& \\ V. MATTI O. LUOSTARINEN
}

\begin{abstract}
Bird population changes were studied during the construction of the new Vuosaari Harbour in 2001-2011 (Helsinki, Finland, N60 $14.52^{\prime}$ E $\left.25^{\circ} 9.07^{\prime}\right)$. Part of the monitoring programme was to determine the possible impacts of harbour and ship channel construction on breeding seabird populations. The study revealed that the population trends of most species showed no substantial difference between islets close to harbor and channel and more distant reference islet. A Black-headed Gull colony was destroyed by landfill but that was deliberately and with permission. The trends of Ruddy Turnstone and Great Black-backed Gull populations were more negative in near than in distant islets. In the surrounding archipelago, the Barnacle Goose, Mew Gull and Common Black-headed Gull clearly increased during the study years. The European Herring Gull decreased distinctly, which was probably caused by the removal of individuals from the rubbish dumps around Helsinki. There were some differences between the restricted-

and open-access islands. The population of Herring Gull was higher and the decline stronger in the restricted areas, while the Common Ringed Plover population simultaneously increased.

Rauno A. Yrjölä, Environmental Research Yrjölä ltd, P.O. Box 62, 01800 Klaukkala, Finland, and Department of Biosciences, Ecology and Evolutionary Biology, P.O. Box 65, 00014 University of Helsinki. Email: rauno.yrjola@yrjola.fi

Jukka A. Rintala, Natural Resources Institute Finland (Luke), Viikinkaari 4, 00790 Helsinki

Hannu Pietiäinen, Department of Biosciences, Ecology and Evolutionary Biology, P.O. Box 65, 00014 University of Helsinki

V. Matti O. Luostarinen, Keijukaistenpolku 7 C 21, 00820 Helsinki
\end{abstract}

Received 20 June 2016, Accepted 5 September 2016, Editor: S. Svensson

\section{Introduction}

The seabird populations of the northern Baltic Sea are threatened by many different factors. Boating and other disturbances such as fishing, eutrophication, feral mink, birds of prey, weather, toxic substances and many other factors have been mentioned as the probable causes of poor fledgling production and seabird population declines (Hario \& Uuksulainen 1993, Hario et al. 1987, Nordström et al. 2003, Hario 2004, Hario, Mazerolle, Saurola 2009, Skov et al. 2011, Hario \& Rintala 2011, 2014). Dredging, dumping and harbour construction probably bring about negative impacts on seabirds breeding at sites near construction areas.

Most studies of the effects of human activity impacts on the environment have been conducted in Europe and North America. Environmental Impact Assessments (EIAs) were first formally established in the USA in 1969, and in 1985 the European
Community directive on EIAs was introduced (Glasson et al. 1994, 2012). During recent decades, the ecological effects of urbanization and other human activities have been widely studied, and several reports have been compiled on the subject (McDonnell et al. 2009, Niemelä 2011). The sphere of influence of urbanization and the direction and size of its effect on animals may vary, depending on the habitat type and the spatiotemporal scale of human activities. Some species are also more sensitive than others. The negative effects of urbanization, e.g. on birds, may extend to areas as far as several kilometres away from the source of the disturbance (Watts \& Bradshaw 1994, Kala- ja Vesitutkimus Oy et al. 1996, Rodgers \& Smith 1997, Mensing et al. 1998). Even small variations from the human standpoint in distance between the disturbance source and birds or in vessel speed can translate into remarkable variation in the disturbance ef- 
fect. For example, the disturbance of boat traffic on foraging Black Guillemots Cepphus grylle was studied at a breeding colony in the Bay of Fundy, Canada, showing that the species was susceptible to disturbance by approaching vessels. The investigators concluded that guillemot flushing probability would be reduced by $10 \%$ any time on condition that a setback distance of at least $600 \mathrm{~m}$ from the shore was established and maximum speed limited to $25 \mathrm{~km} / \mathrm{h}$ (Ronconi \& St. Clair 2002). In another study, a general setback distance of $50 \mathrm{~m}$ between boats and birds was estimated to be sufficient to prevent disturbances to most seabird nesting and roosting sites while allowing viewers to appreciate the seabirds; at shorter distances, the disturbance effect on birds was clearly strengthened (Chatwin et al. 2013).

The planning of a new harbour in Helsinki was initiated as early as the mid-1960s, with the aim of starting the Vuosaari Harbour project in 1992. The EIA procedure of the project was initiated in 1994, when the new environmental act came into force. The town council of Helsinki accepted the establishment plan of the harbour in 1996 (Heikkonen 2008).

The harbour was located next to a Natura 2000 area (F10100065, 'Mustavuoren lehto ja Östersundomin lintuvedet'). Before the start of the project, environmental authorities and nature protection organizations argued, that construction of a new harbour and road connections could seriously affect breeding bird populations. They also argued that enough knowledge was not available, and that construction was not permissible according to so called precautionary principle.

The effects of harbour construction on the Natura values were investigated based on various monitoring programmes. The objective of these programmes was to prevent possible harmful environmental effects and to document the impacts observed and methodology used. The monitoring programmes were carried out as a cooperative project between the Helsinki Environment Centre and the Port of Helsinki. One part of the operation included the monitoring of birds, which began in the archipelago in 2001 and on the land areas in 2002 and continued to as recently as 2011 (Koskimies 2001).

About 30-40 species of seabirds (ducks, geese, waders, gulls and divers) are found in the Gulf of Finland, which are common breeders or migrants along shoreline areas. The most abundant breeding seabird species in the sea area are the Common Eider Somateria mollissima, Black-headed Gull La- rus ridibundus, Mew Gull Larus canus, Arctic Tern Sterna paradisaea and European Herring Gull Larus argentatus (Hario \& Rintala 2011).

The populations of many seabird species have exhibited remarkable long-term trends at large spatial scales, and for many species the mechanisms driving these trends are often unknown. In addition to natural reasons, the causes may be related to human activities. During recent decades, the Barnacle Goose Branta leucopsis, Canada Goose Branta canadensis and Great Cormorant Phalacrocorax carbo numbers have increased rapidly, especially in the western part of the Gulf of Finland (Hario \& Rintala 2011). These species have benefited from various human activities with the consequence of developing new foraging and resting areas, and larger fish stocks, resulting from eutrophication.

The purpose of this study was to investigate the effects of the Vuosaari Harbour and ship channel construction on the local seabird populations. We aimed at revealing possible changes in the archipelago bird populations near the construction area and at pointing out the factors that had altered the population trends. In particular, our study concerned the population trends of rare or vulnerable species. From the environmental management standpoint, the focus was on whether construction had such negative effects on birds that could be avoided or mitigated during similar construction processes. During the monitoring project, the port and environmental authorities were informed regularly about the annual results from the field.

\section{Materials and methods}

The seabird populations were monitored, using yearly breeding bird counts. The monitoring continued for three years after opening of the Vuosaari Harbour in November 2008. The possible effects on the seabird populations were investigated in two areas. One area included islets within two kilometers from the harbor and ship channel. Another area included islets at a larger distance than two kilometers. The birds in the former area were considered to be at risk of disturbance and we call this area the risk area. We assumed that two kilometers was sufficient to exclude disturbance and this area is our reference area.

\section{Study areas}

The risk area comprised 17 islets (Figure 1). Two islets, Varisluoto and Västinki, were covered by harbour landfills and the construction area in 2004, 




Figure 1 The study area. The risk islets are marked with black circles and reference islets with triangles. Dredging, dumping and mining areas are also shown.

Undersökningsområdet. Öar med störningsrisk markerade med svart cirkel och referensöar med triangel. Område för schaktning och dumpning markeras också.

with permission of the authorities. Västinki, an islet with a colony of Black-headed Gulls (200 pairs), was covered with landfills after the breeding season, preventing breeding in subsequent years. All except one risk islet were open-access or under recreational use. Usually, in the archipelagoes between the communes of Sipoo and Espoo, the nesting success of seabirds has been poorer on open islets subject to recreational use than on islets in the conservation or military areas (Matti Luostarinen, personal observations).

The reference area included 21 islets (Figure 1). They were selected, based on their seabird fauna, to be similar to the risk islets at the same distance from the harbour. Open-access and recreational use were allowed for 12 islets. Nine islets had restricted access: three were military areas and the remaining six were nature reserves.

The islets in the archipelago differ: the inner archipelago islets are more luxuriant, and their shores are usually less susceptible to eroding surge. In the outer archipelago, the islets are more rugged. Hence, the seabird communities also differed along the inner/outer archipelago aspect.

\section{Seabird population counts}

The seabird counts of the monitored islets were based on the bird monitoring programme in Koskimies (2001) that was part of the larger monitoring 
programme on the impacts of the Vuosaari Harbour project. Matti Luostarinen performed all the counts during the years 2001-2011.

We aimed at visiting each islet three or four times during the breeding season. In May, the early breeders were counted. In June, the numbers of late breeders were registered, and the adult birds of these species and the young of the early-nesting species were ringed. In late June to early July, the young of the late-nesting species were ringed.

During several survey years, bad weather occasionally prevented fieldwork, and some islets were visited fewer than three times during a season. Counts were taken during a 15-30-min stay per islet; a longer census time would have resulted in damage to the nesting sites. In some locations, the terrain was so difficult that the time-consuming nest censuses were not done so as to minimize disturbance; in these cases, we quickly performed a rough population estimate, based on the number of adult birds in the vicinity of the breeding colonies. On the breeding islets of the Caspian Tern Hydroprogne caspia, the counts were performed with special care and rapidly.

We combined the numbers of Common Tern Sterna hirundo and Arctic Tern, because at some mixed-breeding sites the periods required for separating all adult birds would have been too lengthy, and only the number of 'terns' was counted. Note that the number of reference islets was higher, and thus the total population of terns on these reference islets could have been larger despite the lower mean number of pairs.

\section{Statistical analyses}

The purpose of testing was to reveal possible differences in population size or trends between the risk and reference islets. For the statistical analyses, the area factor classified each islet as (1) a risk or (2) a reference islet, and the use-of-islet factor classified the islets as either (1) open-access or (2) restricted-access, due to their protected or military use status.

To estimate the differences in species-specific population trends by risk/reference and open-access/restricted areas, each species having a total number of more than 30 pairs was analysed with generalized additive mixed models (GAMMs), primarily for denoting the smooth term (Wood 2004, Zuur et al. 2009) of the trends by the spatial treatment (i.e. the trends between the risk and reference islets) and generalized linear mixed models (GLMMs) for revealing the interactions of the year-effect and the spatial treatment and island type (i.e. open-access vs. restricted-access). The islet or island identification code was set as a random effect, and the first-order residual temporal autocorrelation structure was controlled in all models. The GAMMs were performed, using the function gamm of library mgcv (mixed GAM (generalized additive model) computation vehicle) and the GLMMs with the function glmmPQL (glmm Program Query Language) of library MASS (Modern Applied Statistics with S) (Venables \& Ripley 2002) in R vers. 3.1.2 (R Core Team 2014). Passerine species were not tested, because on many islets the population data of these species were only of the present/absent type. The Black Guillemot bred only on the reference islets.

\section{Results}

In all, 28 seabird species were observed breeding on the risk islets during the study period in 20012011 , and the annual total pair number of these varied from 980 to 1196 . For the reference islets, the corresponding numbers were 32 species and pair numbers varying from 1090 to 1615 (Appendix 1).

Species-specific models revealed several significant parameter effects on the overall trends and deviations in the trends between the risk and reference areas, as well as inter-area variation in islet-specific pair densities (Table 1, Figure 2). The Ruddy Turnstone Arenaria interpres trend was somewhat more negative in the risk than in the reference area, as was the trend for the Great Blackbacked Gull Larus marinus.

The pair numbers of the Mute Swan Cygnus olor decreased generally, showing lower densities on the reference islets. The Canada Goose numbers increased significantly on the reference islets, but not on the risk islets. The numbers of Barnacle Goose increased slightly faster on the reference than on the risk islets.

The Mallard Anas platyrhynchos declined significantly on both the risk and reference islets, showing significantly higher pair densities on the reference islets. The Tufted Duck Aythya fuligula declined significantly, particularly on the reference islets. The numbers of Common Eider showed exponential increases on both the reference and risk islets during recent years.

The Eurasian Oystercatcher Haematopus ostralegus showed general increases on both the risk and reference islets. The numbers of Common Redshank Tringa totanus decreased slightly, particularly on the risk islets at the beginning of the study 
Table 1 Statistically significant parameters (Term) affecting seabird numbers, based on two model types (m.typ): generalized additive mixed models (GAMM) and generalized linear mixed models (GLMM). The coefficient is the parameter value indicating the direction and strength of the effect, with its standard errors (Std.Er), degrees of freedom (DF), t-statistics (t) and statistical significance (p).

Statistiskt signifikanta parametrar (Term) som påverkar antal sjöfåglar enligt två modeller (m.type). Coefficienten anger riktning och styrka för effekten (med standardfel, frihetsgrader, $t$-värde och signifikans).

\begin{tabular}{|c|c|c|c|c|c|c|c|}
\hline Species & Term & Coefficient & Std.Error & $\mathrm{DF}$ & $\mathrm{t}$ & $\mathrm{p}$ & m.type \\
\hline Canada Goose & Year:Reference area & 0.223941 & 0.097676 & 368 & 2.292687 & 0.0224 & GAMM \\
\hline \multirow[t]{3}{*}{ Barnacle Goose } & Year:Risk area & 0.789187 & 0.218527 & 368 & 3.611395 & 0.0003 & GAMM \\
\hline & Year:Reference area & 1.887489 & 0.465917 & 368 & 4.051128 & 0.0001 & GAMM \\
\hline & Year & 0.2425 & 0.02735 & 368 & 8.865754 & 0.0000 & GLMM \\
\hline \multirow[t]{3}{*}{ Mute Swan } & Year & -0.01056 & 0.00116 & 366 & -9.07058 & 0.0000 & GLMM \\
\hline & Reference area & -193.182 & 20.58107 & 34 & -9.38638 & 0.0000 & GLMM \\
\hline & Year:Reference area & 0.09587 & 0.01024 & 366 & 9.360752 & 0.0000 & GLMM \\
\hline \multirow[t]{5}{*}{ Mallard } & Year:Risk area & -0.44206 & 0.14119 & 368 & -3.13096 & 0.0019 & GAMM \\
\hline & Year:Reference area & -0.73385 & 0.127865 & 368 & -5.73929 & 0.0000 & GAMM \\
\hline & Year & -0.1369 & 0.0000 & 366 & -119.584 & 0.0000 & GLMM \\
\hline & Reference area & 151.9121 & 3.0000 & 34 & 50.85635 & 0.0000 & GLMM \\
\hline & Year:Reference area & -0.0759 & 0.0000 & 366 & -59.4027 & 0.0000 & GLMM \\
\hline \multirow[t]{2}{*}{ Tufted Duck } & Year:Reference area & -0.1692 & 0.068136 & 368 & -2.48329 & 0.0135 & GAMM \\
\hline & Year & -0.04082 & 0.01606 & 368 & -2.54092 & 0.0115 & GLMM \\
\hline Common Eider & Year & 0.04226 & 0.0165 & 366 & 2.556274 & 0.0110 & GLMM \\
\hline Oystercatcher & Year & 0.04525 & 0.02045 & 368 & 2.212871 & 0.0275 & GLMM \\
\hline \multirow[t]{8}{*}{ Ringed Plover } & Year:Risk area & 1.908575 & 0.779237 & 368 & 2.449288 & 0.0148 & GAMM \\
\hline & Year & 0.123 & 0.03622 & 366 & 3.395585 & 0.0008 & GLMM \\
\hline & Reference area & 649.9509 & 119.2349 & 34 & 5.451011 & 0.0000 & GLMM \\
\hline & Restricted area & 336.2443 & 152.4899 & 34 & 2.205026 & 0.0343 & GLMM \\
\hline & Year:Reference area & -0.3239 & 0.05946 & 366 & -5.4478 & 0.0000 & GLMM \\
\hline & Year:Resticted area & -0.1656 & 0.07601 & 366 & -2.17872 & 0.0300 & GLMM \\
\hline & Reference area:Restricted area & -872.391 & 196.9603 & 34 & -4.42927 & 0.0001 & GLMM \\
\hline & $\begin{array}{l}\text { Year:Reference area: } \\
\text { Restricted area }\end{array}$ & 0.4329 & 0.09819 & 366 & 4.408679 & 0.0000 & GLMM \\
\hline Redshank & Year & -0.08144 & 0.0000 & 366 & -2.05288 & 0.0408 & GLMM \\
\hline \multirow[t]{2}{*}{ Ruddy Turnstone } & Year:Risk area & -0.34523 & 0.119338 & 368 & -2.8929 & 0.0040 & GAMM \\
\hline & Year & -0.11182 & 0.03801 & 368 & -2.94229 & 0.0035 & GLMM \\
\hline \multirow{2}{*}{ Mew Gull } & Year:Reference area & 0.062564 & 0.025878 & 368 & 2.417683 & 0.0161 & GAMM \\
\hline & Year & 0.04179 & 0.00922 & 366 & 4.531292 & 0.0000 & GLMM \\
\hline $\begin{array}{l}\text { Great Black- } \\
\text { backed Gull }\end{array}$ & Year:Risk area & -0.42825 & 0.103255 & 368 & -4.14753 & 0.0000 & GAMM \\
\hline \multirow[t]{3}{*}{ Herring Gull } & Year & -0.03796 & 0.01881 & 368 & -2.0176 & 0.0444 & GLMM \\
\hline & Restricted area & 204.1474 & 47.46774 & 35 & 4.300761 & 0.0001 & GLMM \\
\hline & Year:Resticted area & -0.10177 & 0.02367 & 368 & -4.29891 & 0.0000 & GLMM \\
\hline \multirow{4}{*}{$\begin{array}{l}\text { Lesser Black- } \\
\text { backed Gull }\end{array}$} & Year:Risk area & 1.203814 & 0.147891 & 368 & 8.139853 & 0.0000 & GAMM \\
\hline & Year & 0.3916 & 0.0000 & 366 & 8.782242 & 0.0000 & GLMM \\
\hline & Reference area & 837.9104 & 90.0000 & 34 & 9.327097 & 0.0000 & GLMM \\
\hline & Year:Reference area & -0.4164 & 0.0000 & 366 & -9.3137 & 0.0000 & GLMM \\
\hline $\begin{array}{l}\text { Black-headed } \\
\text { Gull }\end{array}$ & Year:Reference area & 2.40681 & 0.370284 & 368 & 6.499902 & 0.0000 & GAMM \\
\hline $\begin{array}{l}\text { Common and } \\
\text { Arctic Tern total }\end{array}$ & Year:Reference area & -1.1795 & 0.355281 & 368 & -3.3199 & 0.0010 & GAMM \\
\hline
\end{tabular}


Figure 2. Modelled population changes of some seabird species on the risk and reference islets.

Modellerade beståndsförändringar för vissa sjöfåglar på risköar och referensöar.

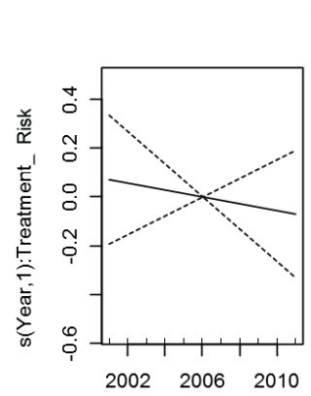

\section{Mute Swan}

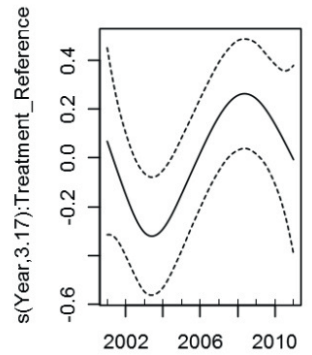

mallara
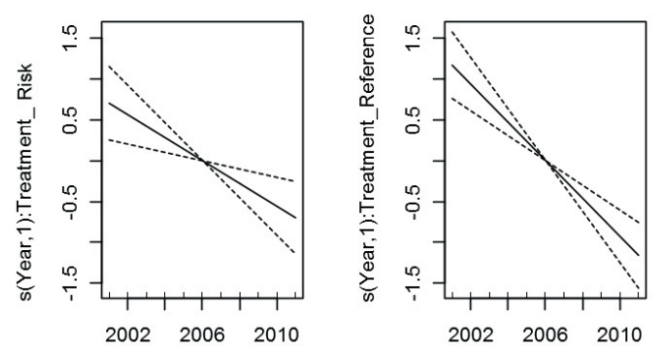

Common Eider
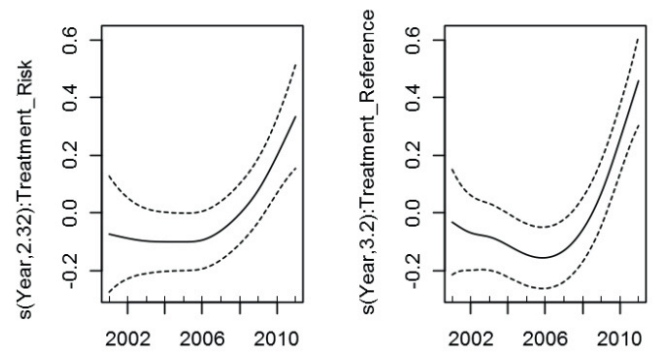

Common Ringed Plover
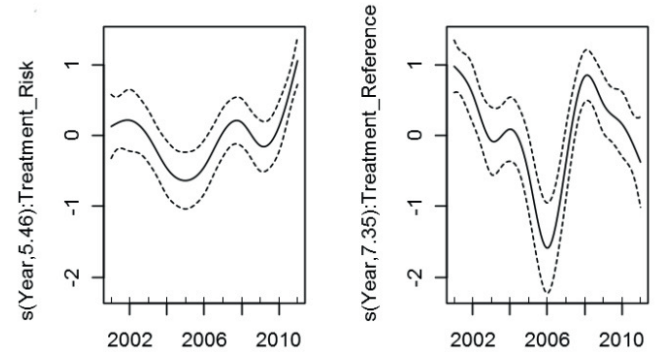

Barnacle Goose
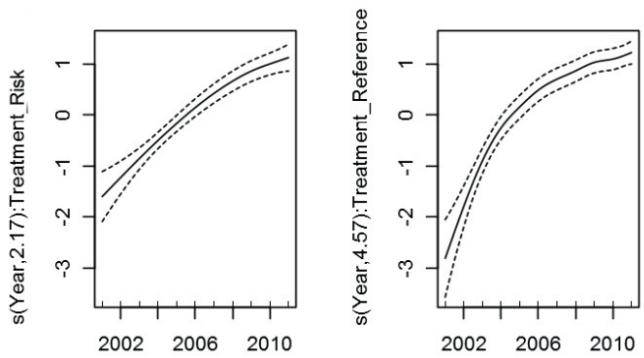

I Urtea vuck
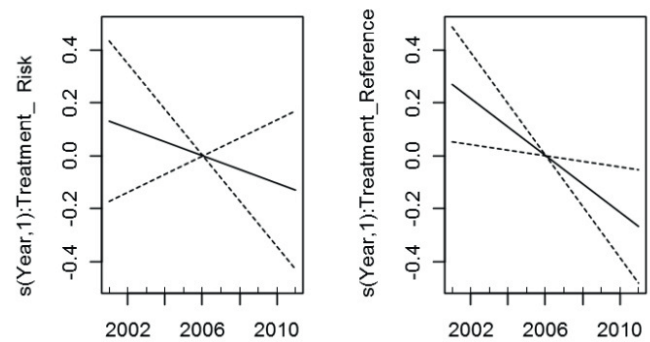

Common Redshank
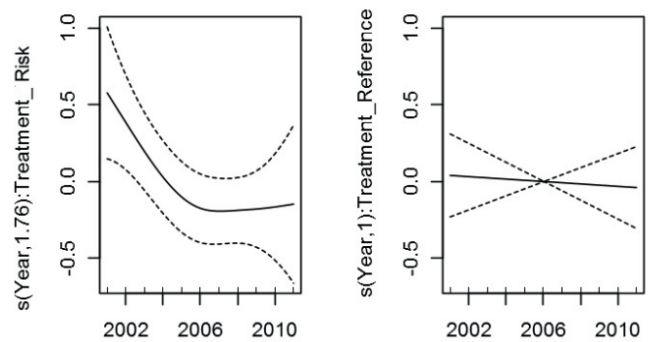

Great Black-backed Gull
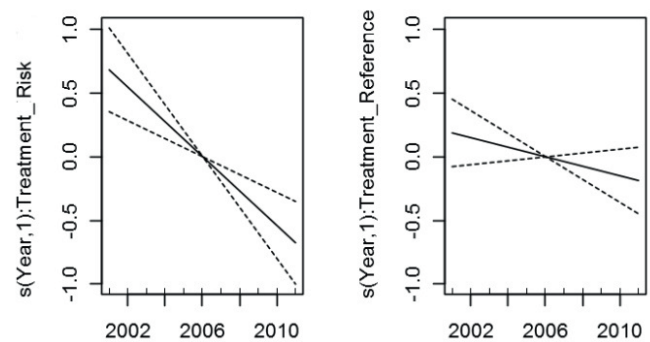


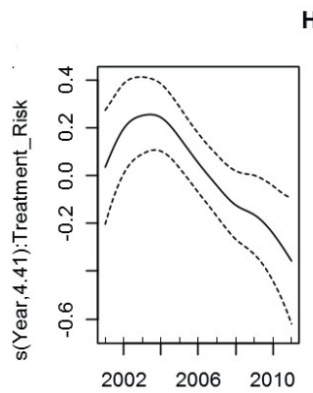

Herring Gull



Mew Gull
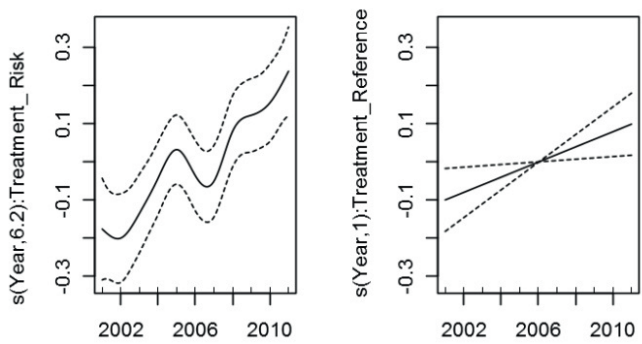

Arctic \& Common Tern
Lesser Black-backed Gull
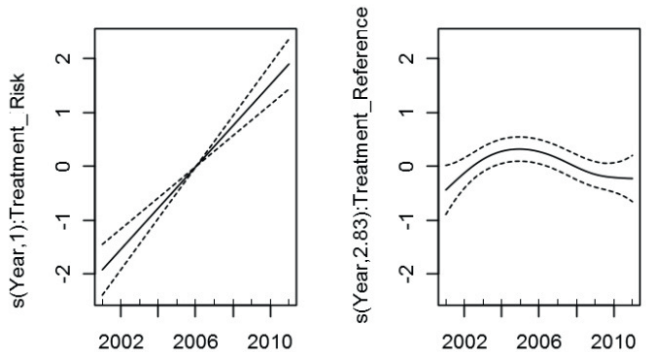

Black-headed Gull
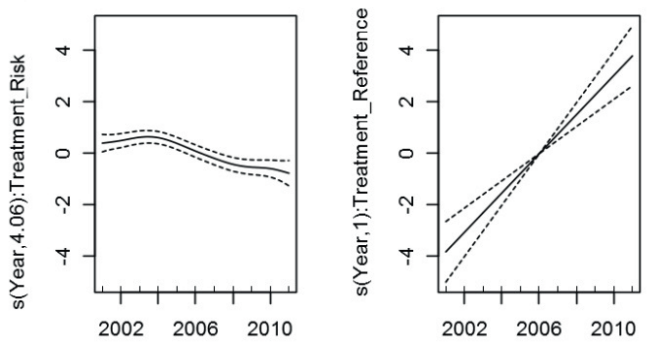
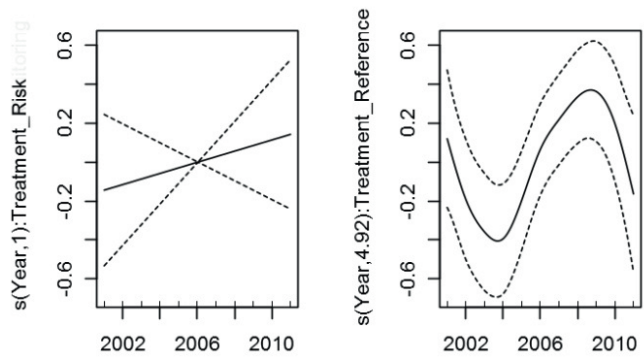

period. The Common Ringed Plover Charadrius hiaticula densities were generally higher on the reference than on the risk islets. In the risk area, the densities were generally highest on the restricted islets. However, in the reference area, the densities were lowest but temporally increased most quickly on the restricted islets (Table 1).

Our monitoring data revealed the most substantial changes in numbers for highly colonial species such as the gulls (Table 1, Figure 2). The European Herring Gull population showed a general decline, with highest densities on the restricted-access islets. The Lesser Black-backed Gull Larus fuscus increased significantly on the risk islets, while the Mew Gull increased, particularly on the reference islets, but also in the risk area. At the beginning of the study period, the Black-headed Gull was more numerous on the risk than on the reference islets. However, during and after the harbour construc- tion, the pair numbers increased significantly in the reference area.

The numbers of the Common Tern and Arctic Tern fluctuated substantially during the study period (Figure 2), but the modelling indicated no clear associations with the environmental change. The nonlinear model suggested a population decrease on the reference islets.

\section{Discussion}

The Vuosaari Harbour and ship channel construction represent one aspect of the urbanization process in the City of Helsinki, which has been intensifying and expanding during recent decades. The number of people in the region of Helsinki is increasing, and the recreation pressure on the archipelago area is strong. The influence of urbanization on bird populations varies, depending on the re- 
quirements of a species, but previous observations have shown that construction activity can easily result in negative impacts. The behaviour of gulls and ducks was monitored during a certain new construction activity in Helsinki, which indicated that these seabirds were frightened by the noise at a distances of hundreds of metres (Kala- ja Vesitutkimus Oy et al. 1996). Similar results were also reported with Great Blue Heron Ardea herodias and foraging waterfowl species from Chesapeake Bay and Florida in the USA (Watts \& Bradshaw 1994, Rodgers \& Smith 1997).

Despite of human activities, the populations of some seabird species have quite uniform trends along wide coastal areas of Finland. For example, the population size developments of Canada Goose, Barnacle Goose, Tufted Duck, Common Redshank, Ruddy Turnstone and European Herring Gull in the Gulf of Finland and other sea areas of southern Finland showed quite synchronous patterns compared with our results.

In our study area the Mallard and Tufted Duck declined during the study years. A similar development has been going on in the longer period1986-2013, when the Tufted Duck decreased moderately in Finland (Hario \& Rintala 2014). The Mallard has increased slightly in inland lake areas (Lehikoinen et al. 2013, Pöysä et al. 2013), but in the archipelago, the species has apparently shown no general population trends (Hario \& Rintala 2014).

The Canada Goose and particularly the Barnacle Goose have increased along the coastal Gulf of Finland (Hario \& Rintala 2014). Based on our results, the Canada Goose population increased during the very beginning of the study period, but decreased slightly during recent years. The Barnacle Goose population increased strongly in our study area, and this species has adapted very well in breeding in Helsinki city. They breed in the archipelago, but use fields, golf courses or even city parks as feeding areas during summer and autumn. The first pair bred in Helsinki in 1989, and in 2009 the population was estimated at 900 breeding pairs and more than 8000 staging individuals in autumn (Väänänen et al. 2010).

Human has had a strong influence on population changes of large gull species. In the early 20th century, only a few European Herring Gull pairs were breeding in the archipelago southwest of Helsinki. In the early 1980 s, the population increased to about 6500 pairs. This population expansion may have been due to the easy availability of edible refuse in rubbish dumps. At the same time, the
Great Black-backed Gull population also increased (Bergman 1982), and single breeding pairs still breed in the area. The increase in the European Herring Gull population has resulted in various problems. The number of individuals has increased in rubbish dumps and throughout Helsinki. Some individuals became specialized in preying on Common Eider ducklings or the chicks of smaller gull species. Such behaviour is typical for the Great Black-backed Gull (Bergman 1982). Together with other problems, predation by European Herring Gulls was partly responsible for the decline in the Lesser Black-backed Gull (Hario 1990). During 2004-2007, a special project was targeted at reducing the number of European Herring Gulls around Helsinki. In total, about 15000 European Herring Gulls and 600 Great Black-backed Gulls were culled at four large open-plan refuse dumps in Uusimaa Province. The aim of the project was to minimize the nuisance effects on humans caused by dense flocks of gull individuals in cities and to reduce the predation pressure on Lesser Blackbacked Gull chicks (Hario, Rintala, Tanner 2009). The culling project succeeded fairly well and the European Herring Gull population decreased rapidly after initiation of the project. This was most probably why the European Herring Gull population also decreased in our study area.

In comparison to the large gull species, the populations of the Mew Gull, Lesser Black-backed Gull and Black-headed Gull have increased in our study area. This may have resulted from the presence of fewer predatory European Herring Gull and Great Black-backed Gull individuals after the culling project. Construction of the Vuosaari Harbour and landfills on the Varisluoto and Västinki islets (Figure 1) during 2003-2004 reduced the number of Black-headed Gulls. However, when all the islets were examined, the total pair numbers of Blackheaded Gulls returned to the levels observed in the early 2000 s, i.e. more than 250 pairs. At the beginning of the study period, there were no Blackheaded Gulls on the reference islets. During the last few study years, the numbers on the reference islets increased rapidly, which may have been due to individuals moving from the Västinki islet; the immigration of new individuals from elsewhere is another possibility. Nationwide, the Black-headed Gull declined in the early 2000s, but later its population began again to increase (Hario \& Rintala 2014).

Larger gulls also prey on terns and small waders. Tern populations have been stable in our area. In other areas, the Mew Gull and Common Tern have 
increased, while the Lesser Black-backed Gull has decreased (Hario \& Rintala 2008, 2011, 2014). The population of Common Redshank decreased, both on the risk and reference islets during the study years. Only the Common Ringed Plover population increased slightly, especially on the restricted-reference islets. The Archipelago Bird Census revealed that the Common Ringed Plover has moderately increased and the Ruddy Turnstone and Common Redshank have moderately decreased in the coastal areas of Finland during 1986--2013 (Hario \& Rintala 2014).

Nesting archipelago birds are more often disturbed on open-access islets than in restrictedaccess conservation or military areas (Matti Luostarinen, personal observations). The population of Common Ringed Plover was increasing on restricted access islets in the reference area, where disturbance is lowest. Also the density of European Herring Gull population was highest there. The trends of Ruddy Turnstone and Great Blackbacked Gull populations were somewhat more negative in the risk than in the reference areas. This may have been a random result, or these species may be more sensitive to human disturbance than others. Most species showed no difference between trends on the risk and reference islets. Other studies have shown that in Finland more Common Eiders breed in protected areas than would otherwise be expected considering the total extent of these areas (Kilpi 1997). Protected archipelago areas will be even more crucial to conservation of future seabird populations.

Our analysis revealed no clear evidence that the populations of the species studied have undergone severe stress from the environmental changes resulting from the Vuosaari Harbour project. Most of the population changes were probably associated with processes acting over larger areas, which thus affected the overall populations and may also have masked processes arising from local disturbances.

However, the type of islet also affected the temporal and spatial patterns of certain species. Both area and islet type affected some populations, particularly the patterns of highly colonial species, such as gulls and terns. The fact that our study did not reveal negative impacts caused by construction of the harbour to most of the monitored species does not necessary rule out disturbance effects. Examining only the number of pairs does not necessarily enable estimation of direct individual impacts. When populations increase, poor-quality areas may also be occupied, often by young and unexperienced individuals. This can prevent de- termination of the real effects of construction. The poor breeding success may have been masked by individuals that originated from other areas. In the future we need to develop better monitoring methods, to monitor population changes, but also individual reproduction and survival rates of nearby breeding birds during large construction projects.

\section{Acknowledgements}

We are grateful to Antero Järvinen for his valuable and constructive comments. Andreas Lindén helped us with the statistical analysis. Jukka Tanner gave us the data and results of the European Herring Gull removal project. In particular, we want to thank all the fieldworkers and members of the Vuosaari Bird Study team: Matti Koivula, Jarkko Santaharju, Matti Luostarinen, Hannu Sarvanne, Antti Tanskanen, Jorma Vickholm, Jari Kontiokorpi and Thomas Oesch (deceased). Without their hard work, this study would not have been possible.

\section{References}

Bergman, G (1982) Population dynamics, colony formation and competition in Larus argentatus, fuscus and marinus in the archipelago of Finland. Annales Zoologici Fennici 19:143-164.

Chatwin TA, Joy R, Burger AE (2013) Set-back distances to protect nesting and roosting seabirds off Vancouver Island from boat disturbance. Waterbirds 36:43-52.

Glasson J, Therivel R, Chadwick A (1994) Introduction to environmental impact assessment. Principles and procedures, process, practice and prospects. UCL, London. $342 \mathrm{pp}$.

Glasson J, Therivel R, Chadvik A (2012) Introduction to environmental impact assessment. Routledge, London \& New York. 392 pp.

Hario M (1990) Breeding failure and feeding conditions of Lesser Black-backed Gulls Larus f. fuscus in the Gulf of Finland. Ornis Fennica 67:113-129.

Hario M (2004) Organochlorine concentrations in diseased vs. healthy gull chicks from the northern Baltic. Environmental Pollution 127:411-423.

Hario M, Kastepõld T, Kilpi M, Staav R, Stjernberg T (1987) Status of Caspian Terns Sterna caspia in the Baltic. Ornis Fennica 64:154-157.

Hario M, Mazerolle MJ, Saurola P (2009) Survival of female common eiders Somateria m. mollissima in a declining population of the northern Baltic Sea. Oecologia 159:747-756.

Hario M, Rintala J (2008) Haahkan ja lokkien kannankehitys rannikoilla 1986-2007. Linnut vuosikirja 2007: 52-59. (In Finnish with English summary).

Hario M, Rintala J (2011) Saaristolintukantojen kehitys Suomessa 1986-2010. Linnut vuosikirja 2010: 40-51. (In Finnish with English summary).

Hario M, Rintala J (2014) Saaristolinnuston kehitys Suomen 
rannikolla 1986-2013. Linnut vuosikirja 2013 :46-53. (In Finnish with English summary).

Hario M, Rintala J, Tanner J (2009) Keskisen Suomenlahden harmaalokkiprojekti. Kannanrajoitustoimet 2004-2007. Riista- ja kalatalous - tutkimuksia. (In Finnish with English summary).

Hario M, Uuksulainen J (1993) Mercury load according to moulting area in primaries of the nominate race of the Lesser Black-backed Gull Larus $f$. fuscus. Ornis Fennica 70:32-39.

Heikkonen M (2008) Vuosaaren satama ja ympäristö. Suunnittelusta rakentamiseen. Vuosaaren satamahanke. 181 pp. (In Finnish with English summary).

Kala- ja Vesitutkimus Oy, Mikkola-Roos M, Hirvonen $\mathrm{H}$ (1996) Toukolanranta, rakentamisen ympäristövaikutukset. Ekologinen näkökulma II. Helsingin kaupunkisuunnitteluviraston julkaisuja 1996:20. (In Finnish).

Kilpi M (1997) Saaristolinnuston suojelun nykytaso Suomen rannikolla. In: Kilpi, M. \& Asanti, T. (eds.) Saaristolinnuston suojelun nykytila Suomen rannikolla. Suomen ympäristö 103:1-37. (In Finnish with English summary).

Koskimies P (2001) Vuosaaren satamahankkeen luontovaikutusten seurantaohjelma. Osa 1. Linnustovaikutusten seurantaohjelma. Helsingin kaupungin ympäristökeskuksen julkaisuja. 30 pp. (In Finnish with English summary).

Lehikoinen A, Pöysä H, Rintala J, Väisänen RA (2013) Suomen sisävesien vesilintujen kannanvaihtelut 1986-2012. Linnut vuosikirja 2012:95-101. (In Finnish with English summary).

McDonnell MJ, Hahs AK, Breuste J (2009) Ecology of cities and towns. A comparative approach. Cambridge University Press, Cambridge, UK, New York. 714 pp.

Mensing DM, Galatowitsch SM, Tester JR (1998) Anthropogenic effects on the biodiversity of riparian wetlands of a northern temperate landscape. Journal of Environmental Management 53:349-377.

Niemelä J (2011) Urban ecology. Patterns, processes, and applications. Oxford University Press, Oxford [England], New York. 374 pp.

Nordström M, Högmander J, Laine J, Nummelin J, Laanetu N, Korpimäki E (2003) Effects of feral mink removal on seabirds, waders and passerines on small islands in the Baltic Sea. Biological Conservation 109:359-368.

Pöysä H, Rintala J, Lehikoinen A, Väisänen RA (2013) The importance of hunting pressure, habitat preference and life history for population trends of breeding waterbirds in Finland. European Journal of Wildlife Research 59:245-256.

Rodgers JA, Smith HT (1997) Buffer zone distances to protect foraging and loafing water birds from human disturbance in Florida. Wildlife Society Bulletin, 25(1):139-145.

Ronconi RA, St. Clair CC (2002) Management options to reduce boat disturbance on foraging black guillemots (Cepphus grylle) in the Bay of Fundy. Biological Conservation 108:265-271.

Skov H, Heinänen S, Žydelis R, Bellebaum J, Bzoma S, Dagys M, Durinck J, Garthe S, Grishanov G, Hario M, Kieckbusch JJ, Kube J, Kuresoo A, Larsson K, Luigujoe L, Meissner W, Nehls HW, Nilsson L, Petersen IK, Mikkola-Roos M, Pihl S, Sonntag N, Stock A, Stipniece A, Wahl J (2011) Waterbird Populations and Pressures in the Baltic Sea. Tema Nord 550. Norden. 203pp.

Watts B, Bradshaw DS (1994) The influence of human disturbance on the location of Great Blue Heron colonies in the Lower Chesapeake Bay. Colonial Waterbirds 17:184-186.

Väänänen V-M, Laine J, Lammi E, Lehtiniemi T, Luostarinen V-M, Mikkola-Roos M (2010) Suomen valkoposkihanhikanta jatkaa kasvuaan. Linnut vuosikirja 2009: 72-77. (In Finnish with English summary).

\section{Sammanfattning}

I början av 1990-talet inleddes planeringen av den nya Nordsjö Hamn i Helsingfors och 1996 fastställdes planen, vilket innebar att hamnen kom att förläggas nära ett Narura 2000-område. Det fanns farhågor om att arbetena skulle innebära störningar av fågellivet såväl i hamnområdet som längs den farled som skulle konstrueras från hamnen till öppet hav. Farleden passerade ett stort antal öar och skär med häckande fåglar. För att undersöka om de förmodade störningarna hade inverkan på fågellivet genomfördes åren 2001-2011 en övervakning av sjöfåglarna. Undersökningen omfattade 38 fågelskär. Eftersom man förmodade att risken för störningarna inte borde sträcka sig längre ut från hamn och farled än två kilometer uppdelades skären i två kategorier (Figur 1). De innanför två kilometer betraktades som skär med störningsrisk och de jämfördes med de skär som låg utanför som referens. Skären inventerades normalt tre till fyra gånger per år. Tidpunkterna var anpassade till olika arter och faser i häckningsförloppet. Besöken var korta, 15-30 minuter, eftersom längre besök skulle ha kunnat skada fågellivet. Antal par som registrerades framgår av Appendix 1, separat för riskskären och referensskären.

Vilka faktorer som påverkade fågellivet analyserades statistiskt med hjälp av modellering, och de signifikanta faktorerna redovisas i Tabell 1. I Figur 2 jämförs de modellerade beståndsförändringarna mellan risk- och referensområdena.

Totalt registrerades 28 häckande arter med mellan 980 och 1196 par på skären i riskområdet och 32 arter med mellan 1090 och 1615 par i referensområdet. Om enskilda arter kan följande nämnas. Roskarl och havstrut hade mer negativa trender i riskområdet än i referensområdet. Knölsvan minskade generellt och hade lägre täthet i referensområdet. Kanadagås ökade i referensområdet men inte i riskområdet. Vitkindad gås ökade något snabbare i referens- än i riskområdet. Gräsand minskade i båda områdena men hade signifikant högre täthet i referensområdet. Vigg minskade signifikant men särskilt mycket i referensområdet. Ejder uppvisade exponentiell tillväxt $\mathrm{i}$ båda områdena. Även strandskata ökade i båda områdena. Rödbena minskade 
något, särskilt i riskområdet. Större strandpiparens täthet var större i referensområdet än i riskområdet. Inventeringarna visade på störst förändringar för kolonilevande arter såsom måsar. Gråtruten minskade men hade högst täthet på skär med besöksrestriktioner. Silltruten ökade på risköarna medan fiskmåsen ökade på referensöarna. Tärnorna (arterna sammanslagna) varierade mycket $i$ antal men variationen hade inget samband med omvärldsfaktorerna.

Flera av förändringarna i undersökningsområdet är desamma som längs Finlands kust i övrigt, nämligen för kanadagås, vitkindad gås, vigg, rödbena, roskarl och gråtrut. Både havstrut och gråtrut har minskat generellt, troligen som en effekt av soptipparnas försvinnande. Dessa arters predation kan vara förklaringen till att de mindre måsarna, fiskmås, silltrut och skrattmås, kunnat öka i antal. De större måsarna konsumerar också ägg och ungar av tärnor, men tärnornas antal har inte reducerats i området.

Sammanfattningsvis visade vår analys på betydande variation mellan olika arters reaktion på eventuella störningar och effekter av generella storskaliga populationsprocesser. Vi kunde inte påvisa några entydiga eller systematiska effekter av hamn- och farledsbyggandet. De flesta beståndsförändringarna var troligen resultat av processer som verkade över större områden. Vi kan dock inte utesluta att dessa processer kan ha dolt vissa lokala störningseffekter. 
Appendix 1. Yearly number of pairs. Arligt antal par.

\begin{tabular}{|c|c|c|c|c|c|c|c|c|c|c|c|}
\hline \multirow{2}{*}{$\begin{array}{l}\text { Risk Islets } \\
\text { Species }\end{array}$} & \multicolumn{11}{|c|}{ Year } \\
\hline & 2001 & 2002 & 2003 & 2004 & 2005 & 2006 & 2007 & 2008 & 2009 & 2010 & 2011 \\
\hline Cygnus olor & 7 & 11 & 4 & 5 & 7 & 6 & 6 & 9 & 7 & 5 & 8 \\
\hline Branta canadensis & 3 & 3 & 2 & 3 & 2 & 3 & 7 & 4 & 2 & 3 & 3 \\
\hline Branta leucopsis & 2 & 4 & 6 & 11 & 11 & 19 & 24 & 29 & 46 & 35 & 41 \\
\hline Anas penelope & 1 & 0 & 0 & 0 & 0 & 0 & 0 & 0 & 0 & 0 & 0 \\
\hline Anas platyrhynchos & 5 & 5 & 4 & 5 & 5 & 3 & 2 & 2 & 2 & 2 & 1 \\
\hline Anas clypeata & 0 & 2 & 2 & 1 & 2 & 0 & 1 & 0 & 2 & 2 & 0 \\
\hline Aythya fuligula & 23 & 24 & 18 & 19 & 13 & 24 & 4 & 14 & 21 & 17 & 19 \\
\hline Somateria mollissima & 114 & 109 & 103 & 118 & 121 & 92 & 109 & 126 & 101 & 139 & 161 \\
\hline Melanitta fusca & 0 & 0 & 0 & 0 & 0 & 0 & 0 & 0 & 0 & 0 & 1 \\
\hline Bucephala glangula & 0 & 0 & 0 & 0 & 0 & 0 & 0 & 0 & 0 & 0 & 0 \\
\hline Mergus serrator & 1 & 0 & 0 & 0 & 0 & 1 & 0 & 0 & 0 & 1 & 0 \\
\hline Mergus merganser & 0 & 2 & 1 & 0 & 0 & 0 & 0 & 0 & 0 & 0 & 0 \\
\hline Podiceps cristatus & 0 & 0 & 0 & 0 & 0 & 0 & 0 & 0 & 0 & 0 & 0 \\
\hline Haematopus ostralegus & 6 & 4 & 4 & 6 & 6 & 7 & 6 & 9 & 8 & 7 & 6 \\
\hline Charadrius hiaticula & 2 & 1 & 2 & 1 & 1 & 1 & 2 & 3 & 1 & 2 & 5 \\
\hline Actitis hypoleucos & 0 & 0 & 0 & 0 & 1 & 1 & 1 & 0 & 2 & 2 & 1 \\
\hline Tringa totanus & 5 & 5 & 3 & 3 & 1 & 0 & 3 & 4 & 2 & 2 & 2 \\
\hline Arenaria interpres & 5 & 5 & 4 & 3 & 4 & 1 & 4 & 1 & 3 & 3 & 1 \\
\hline Larus ridibundus & 280 & 277 & 385 & 386 & 285 & 184 & 163 & 87 & 95 & 156 & 78 \\
\hline Larus canus & 263 & 171 & 278 & 285 & 349 & 286 & 288 & 346 & 359 & 345 & 382 \\
\hline Larus fuscus & 0 & 0 & 0 & 0 & 1 & 1 & 1 & 2 & 2 & 4 & 4 \\
\hline Larus argentatus & 151 & 196 & 196 & 195 & 180 & 147 & 147 & 116 & 138 & 118 & 102 \\
\hline Larus marinus & 8 & 9 & 8 & 7 & 6 & 5 & 2 & 4 & 3 & 3 & 3 \\
\hline Hydroprogne caspia & 2 & 1 & 1 & 2 & 1 & 1 & 2 & 1 & 1 & 1 & 0 \\
\hline Sterna hirundo & 1 & 1 & 0 & 22 & 0 & 1 & 1 & 0 & 0 & 1 & 2 \\
\hline Sterna paradisaea & 20 & 17 & 18 & 6 & 12 & 8 & 16 & 15 & 20 & 15 & 76 \\
\hline Sterna hirundo/paradisaea & 180 & 136 & 140 & 85 & 91 & 166 & 181 & 200 & 191 & 130 & 135 \\
\hline Cephus grylle & 0 & 0 & 0 & 0 & 0 & 0 & 0 & 0 & 0 & 0 & 0 \\
\hline Anthus petrosus & 3 & 2 & 4 & 1 & 3 & 3 & 4 & 3 & 3 & 4 & 2 \\
\hline Motacilla alba & 11 & 8 & 7 & 13 & 14 & 12 & 11 & 9 & 12 & 11 & 10 \\
\hline Oenanthe oenanthe & 8 & 3 & 5 & 0 & 8 & 6 & 8 & 6 & 5 & 5 & 6 \\
\hline Corvus corone cornix & 0 & 0 & 1 & 2 & 2 & 2 & 2 & 1 & 1 & 1 & 1 \\
\hline Total & 1101 & 996 & 1196 & 1179 & 1126 & 980 & 995 & 991 & 1027 & 1014 & 1050 \\
\hline
\end{tabular}


Appendix 1. Yearly number of pairs. Arligt antal par.

\begin{tabular}{|c|c|c|c|c|c|c|c|c|c|c|c|}
\hline \multirow{2}{*}{$\begin{array}{l}\text { Reference Islets } \\
\text { Species }\end{array}$} & \multicolumn{11}{|c|}{ Year } \\
\hline & 2001 & 2002 & 2003 & 2004 & 2005 & 2006 & 2007 & 2008 & 2009 & 2010 & 2011 \\
\hline Cygnus olor & 9 & 9 & 1 & 6 & 7 & 9 & 8 & 12 & 10 & 9 & 6 \\
\hline Branta canadensis & 3 & 2 & 5 & 3 & 3 & 4 & 6 & 6 & 5 & 6 & 5 \\
\hline Branta leucopsis & 0 & 4 & 13 & 24 & 28 & 45 & 54 & 59 & 80 & 72 & 91 \\
\hline Anas penelope & 1 & 0 & 1 & 0 & 1 & 1 & 0 & 1 & 1 & 1 & 2 \\
\hline Anas platyrhynchos & 10 & 8 & 10 & 6 & 5 & 5 & 1 & 4 & 2 & 1 & 0 \\
\hline Anas clypeata & 1 & 0 & 1 & 0 & 1 & 0 & 0 & 0 & 1 & 1 & 2 \\
\hline Aythya fuligula & 54 & 32 & 55 & 40 & 24 & 42 & 23 & 29 & 40 & 40 & 23 \\
\hline Somateria mollissima & 162 & 134 & 171 & 153 & 139 & 139 & 139 & 150 & 156 & 204 & 265 \\
\hline Melanitta fusca & 0 & 0 & 0 & 1 & 0 & 0 & 0 & 0 & 0 & 1 & 1 \\
\hline Bucephala glangula & 1 & 0 & 1 & 2 & 1 & 1 & 1 & 1 & 0 & 1 & 0 \\
\hline Mergus serrator & 0 & 1 & 0 & 0 & 1 & 1 & 1 & 0 & 2 & 2 & 1 \\
\hline Mergus merganser & 0 & 0 & 1 & 2 & 1 & 2 & 2 & 1 & 1 & 1 & 3 \\
\hline Podiceps cristatus & 0 & 0 & 0 & 0 & 0 & 0 & 0 & 0 & 1 & 0 & 0 \\
\hline Haematopus ostralegus & 6 & 8 & 5 & 8 & 8 & 4 & 3 & 9 & 11 & 9 & 8 \\
\hline Charadrius hiaticula & 4 & 3 & 1 & 2 & 1 & 0 & 1 & 4 & 2 & 2 & 1 \\
\hline Actitis hypoleucos & 0 & 0 & 1 & 0 & 2 & 0 & 0 & 0 & 1 & 0 & 0 \\
\hline Tringa totanus & 6 & 4 & 6 & 6 & 5 & 6 & 5 & 5 & 7 & 4 & 5 \\
\hline Arenaria interpres & 9 & 3 & 5 & 4 & 5 & 2 & 5 & 6 & 6 & 5 & 3 \\
\hline Larus ridibundus & 0 & 0 & 0 & 1 & 0 & 0 & 0 & 21 & 58 & 120 & 300 \\
\hline Larus canus & 347 & 328 & 390 & 384 & 411 & 349 & 419 & 411 & 404 & 408 & 426 \\
\hline Larus fuscus & 1 & 2 & 3 & 3 & 3 & 3 & 3 & 2 & 1 & 2 & 2 \\
\hline Larus argentatus & 189 & 199 & 239 & 251 & 249 & 209 & 200 & 184 & 146 & 124 & 102 \\
\hline Larus marinus & 10 & 8 & 8 & 9 & 7 & 8 & 10 & 6 & 6 & 8 & 6 \\
\hline Hydroprogne caspia & 3 & 2 & 2 & 3 & 2 & 1 & 1 & 1 & 1 & 1 & 2 \\
\hline Sterna hirundo & 22 & 30 & 20 & 44 & 20 & 33 & 15 & 20 & 2 & 4 & 20 \\
\hline Sterna paradisaea & 8 & 6 & 0 & 0 & 1 & 17 & 0 & 5 & 2 & 1 & 0 \\
\hline Sterna hirundo/paradisaea & 390 & 250 & 251 & 168 & 288 & 388 & 436 & 475 & 529 & 364 & 275 \\
\hline Cephus grylle & 24 & 22 & 16 & 26 & 17 & 20 & 26 & 35 & 37 & 24 & 23 \\
\hline Anthus petrosus & 8 & 6 & 7 & 6 & 9 & 7 & 10 & 9 & 8 & 8 & 9 \\
\hline Motacilla alba & 19 & 18 & 14 & 17 & 20 & 15 & 20 & 22 & 21 & 17 & 22 \\
\hline Oenanthe oenanthe & 11 & 11 & 5 & 1 & 11 & 5 & 11 & 7 & 8 & 7 & 12 \\
\hline Corvus corone cornix & 1 & 0 & 0 & 0 & 1 & 0 & 0 & 0 & 0 & 1 & 0 \\
\hline Total & 1299 & 1090 & 1232 & 1170 & 1271 & 1316 & 1400 & 1485 & 1550 & 1450 & 1615 \\
\hline
\end{tabular}

